\title{
Mais um rastro de destruição e morte na história da mineração e da empresa Vale S.A. - Nota da Articulação Internacional dos Atingidos e Atingidas pela Vale S.A. (2015)
}

Articulação Internacional dos Atingidos e Atingidas pela Vale S.A.

Ontem, dia 05 de novembro de 2015, mais uma notícia chocante e terrível envolvendo a grande mineração e a empresa Vale S.A. nos assola.

Duas barragens da mineradora Samarco Mineradora S.A., joint venture da Vale S.A (50\%) e da BHP Billiton Brasil Ltda (50\%), e também recebedora de rejeitos de outras minas da Vale S.A na região, dentre as quais a mina de Alegria, se romperam no estado de Minas Gerais, no distrito de Bento Rodrigues, entre as cidades de Mariana e Ouro Preto.

O Distrito encontra-se completamente soterrado por lama tóxica, sendo o acesso ao local apenas possível por helicóptero. Há inúmeros desabrigados e até o momento foram contabilizados ao menos 16 mortos, 45 desaparecidos e inúmeros soterrados. A situação no local continua muito grave e há riscos de novos desmoronamentos. Inicialmente, somente o distrito de Bento Rodrigues havia sido afetado, mas a enxurrada de rejeitos segue atingindo outros distritos e municípios, tendo chegado a $60 \mathrm{~km}$ do local. 
O rompimento de uma barragem de rejeitos - estrutura que tem a finalidade de reter os resíduos sólidos, que possuem elevado grau de toxicidade e água dos processos de beneficiamento de minério - não se dá de forma aleatória e não é uma novidade nem para o estado de Minas Gerais nem para o setor minerário. A gravidade do caso exige severa investigação sobre o ocorrido, rigorosa responsabilização dos culpados e reparação integral e indenização a todos os afetados e afetadas.

O que ocorreu foi um CRIME. Os órgãos fiscalizadores e as empresas têm total responsabilidade sobre a tragédia ocorrida. A quantidade de rejeitos prova que as empresas tinham ultrapassado, e muito, a capacidade da barragem. O laudo técnico realizado pelo Instituto Prístino, a pedido do Ministério Público durante o licenciamento do projeto, já identificava problemas, tais como: a barragem do Fundão e a pilha de estéril União da Mina de Fábrica Nova da Vale fazem limite entre si, caracterizando sobreposição de áreas de influência direta, com sinergia de impacto; a condicionante de monitoramento geotécnico e estrutural dos diques e da barragem deveria ser realizada periodicamente, com intervalo inferior a um ano, indicando risco de acidentes. Esses dois pontos já anunciavam a tragédia e comprovam a política cruel da Samarco, Vale S.A. e dos órgãos responsáveis pela licença do projeto.

A Vale S.A. é uma empresa amplamente conhecia por movimentos sociais, comunidades, sindicatos, acadêmicos, organizações não governamentais e demais segmentos sociais, por seu constante desprezo aos direitos socioambientais. O que mais esta tragédia nos evidencia é o desrespeito a questões fundamentais, como a segurança, tanto dos seus trabalhadores, quanto das comunidades próximas, frente a crescente intensidade da extração mineral e a busca desenfreada pelo lucro das grandes mineradoras.

No momento atual, em que está em jogo a aprovação de um Novo Código Mineral para o país, que permitirá o avanço ainda maior da mineração em território nacional, deve-se considerar as chances reais do crescimento em escala e números do cenário de mortes, desrespeito de direitos, apropriação ilegal de terras, contaminação de mananciais de água e tragédias como a ocorrida ontem. 
Em Minas Gerais está para ser votado o Projeto de Lei $n^{\circ}$ 2.946/2015, de autoria do atual governador Fernando Pimentel (PT), que fragiliza ainda mais o licenciamento ambiental no estado. $\mathrm{O}$ referido projeto permitirá reduzir o tempo para a concessão do licenciamento ambiental no estado, fato que beneficiará empreendimentos considerados estratégicos pelo Governo, ampliando ainda mais a insegurança jurídica, os danos ambientais e os conflitos sociais associados a grandes projetos.

A tragédia de ontem mais uma vez nos alerta para o constante impacto socioambiental da mineração. Esse desastre pede de forma urgente um debate público sobre a mineração em grande escala no país e os mecanismos de responsabilização das empresas. A política das mineradoras para com os trabalhadores e as comunidades é a mais perversa possível. Essas empresas lucram bilhões todos os anos e investem muito pouco em segurança, nos trabalhadores e nas cidades.

Várias são as denúncias de irregularidades na construção e ampliação de barragens de rejeitos, citando-se a título de exemplo as irregularidades estruturais nas obras que envolvem a barragem da mina Casa de Pedra em Congonhas/MG, da Companhia Siderúrgica Nacional, bem como as ilegalidades no processo de outorga referente à construção da barragem de rejeitos do sistema Minas-Rio, a ser instalada entre os municípios de Alvorada de Minas e Conceição do Mato Dentro, de responsabilidade da mineradora Anglo American.

Para nós da Articulação Internacional dos Atingidos e Atingidas pela Vale S.A. o que ocorreu no distrito de Bento Rodrigues não é um caso isolado e sim mais uma tragédia do setor. Grandes empresas como a Vale S.A. possuem a prática de terceirizar suas operações ou criar joint-ventures escondendo seu nome e omitindo compromissos e responsabilidades. Não podemos deixar que os responsáveis pela tragédia saiam impunes.

Exigimos investigação e punição cível, ambiental e criminal das empresas Samarco, Vale S.A. e BHP Billiton Brasil Ltda, responsabilizando-se, também, seus dirigentes de forma pessoal, além de reparação integral e indenização à população de Bento Rodrigues. 
Nós da Articulação Internacional enviamos toda a solidariedade à população de Bento Rodrigues, Paracatu de Baixo, Mariana e região.

Não podemos permitir nem mais uma morte!

\section{BASTA!}

Articulação Internacional dos Atingidos e Atingidas pela Vale S.A. 